\title{
Patterns in artisanal coral reef fisheries revealed through local monitoring efforts
}

\author{
David G Delaney ${ }^{\text {Corresp., }}{ }_{1,2}$ ， Lida T Teneva ${ }^{3}$ ， Kostantinos A Stamoulis ${ }^{1,4}$ ， Jonatha L Giddens ${ }^{1}$, Haruko Koike ${ }^{1,5}$, \\ Tom Ogawa ${ }^{5}$, Alan M Friedlander ${ }^{1,6}$, John N Kittinger ${ }^{3,7}$ \\ ${ }^{1}$ Fisheries Ecology Research Laboratory, Department of Biology, University of Hawai'i, Honolulu, Hawai'i, United States of America \\ 2 Delaney Aquatic Consulting LLC, Honolulu, Hawai'i, United States of America \\ ${ }^{3}$ Center for Oceans, Conservation International, Honolulu, Hawai'i, United States of America \\ 4 Department of Environment and Agriculture, Curtin University, Perth, Australia \\ 5 Division of Aquatic Resources (DAR), Department of Land and Natural Resources, Honolulu, Hawai'i, United States of America \\ 6 Pristine Seas, National Geographic Society, Washington, DC, United States of America \\ 7 Center for Biodiversity Outcomes, Julie Ann Wrigley Global Institute of Sustainability, Arizona State University, Tempe, Arizona, United States of America \\ Corresponding Author: David G Delaney \\ Email address: dgdelaney@gmail.com
}

Sustainable fisheries management is key to restoring and maintaining ecological function and benefits to people, but it requires accurate information about patterns of resource use, particularly fishing pressure. In most coral reef fisheries and other data-poor contexts, obtaining such information is challenging and remains an impediment to effective management. We developed the most comprehensive regional view of shore-based fishing effort and catch published to date, to show detailed fishing patterns from across the main Hawaiian Islands (MHI). We reveal these regional patterns through fisher "creel" surveys conducted by local communities, state agencies, academics, and/or environmental organizations, at 18 sites, comprising $>10,000 \mathrm{hr}$ of monitoring across a range of habitats and human influences throughout the MHI. All creel surveys included in this study except for one were previously published in some form (peer-reviewed articles or gray literature reports). Here, we synthesize these studies to document spatial patterns in nearshore fisheries catch, effort, catch rates (i.e., catch-per-unit-effort [CPUE]), and catch disposition (i.e., use of fish after catch is landed). This effort provides for a description of general regional patterns based on these location-specific studies. Line fishing was by far the dominant gear type employed. The most efficient gear (i.e., highest CPUE) was spear (0.64 $\left.\mathrm{kg} \mathrm{hr}^{-1}\right)$, followed closely by net $\left(0.61 \mathrm{~kg} \mathrm{hr}^{-1}\right)$, with CPUE for line $\left(0.16 \mathrm{~kg} \mathrm{hr}^{-1}\right)$ substantially lower than the other two methods. Creel surveys also documented illegal fishing activity across the studied locations, although these activities were not consistent across sites. Overall, most of the catch was not sold, but rather retained for home consumption or given away to extended family, which suggests that cultural practices and food security may be stronger drivers of fishing effort than commercial exploitation for coral reef fisheries in 
Hawai'i. Increased monitoring of spatial patterns in nearshore fisheries can inform targeted management, and can help communities develop a more informed understanding of the drivers of marine resource harvest and the state of the resources, in order to maintain these fisheries for food security, cultural practices, and ecological value. 
1 Patterns in artisanal coral reef fisheries revealed through local monitoring efforts

4 David G. Delaney ${ }^{1,2}$, Lida T. Teneva ${ }^{3}$, Kostantinos A. Stamoulis $^{4,1}$, Jonatha L. Giddens ${ }^{1}$, Haruko

5 Koike $^{5,1}$, Tom Ogawa ${ }^{5}$, Alan M. Friedlander ${ }^{1,6}$, and John N. Kittinger ${ }^{3,7}$

$8 \quad{ }^{1}$ Fisheries Ecology Research Laboratory, Department of Biology, University of Hawai'i,

9 Honolulu, Hawai'i, United States of America (USA)

$10{ }^{2}$ Delaney Aquatic Consulting LLC, Honolulu, Hawai‘i, USA

$11{ }^{3}$ Conservation International, Center for Oceans, Honolulu, Hawai‘i, USA

$12{ }^{4}$ Department of Environment and Agriculture, Curtin University, Perth, Australia

$13{ }^{5}$ Department of Land and Natural Resources, Division of Aquatic Resources (DAR), Honolulu, 14 Hawai' $i$, USA

15 'Pristine Seas, National Geographic Society, Washington DC, USA

$16{ }^{7}$ Arizona State University, Center for Biodiversity Outcomes, Julie Ann Wrigley Global Institute 17 of Sustainability, Tempe, Arizona, USA

20 Corresponding Author:

21 Dr. David Delaney

223029 Lowrey Ave., Suite O-2206 Honolulu, HI USA 96822

23 E-mail: dgdelaney@gmail.com 


\section{Abstract:}

Sustainable fisheries management is key to restoring and maintaining ecological function and benefits to people, but it requires accurate information about patterns of resource use, particularly fishing pressure. In most coral reef fisheries and other data-poor contexts, obtaining such information is challenging and remains an impediment to effective management. We developed the most comprehensive regional view of shore-based fishing effort and catch published to date, to show detailed fishing patterns from across the main Hawaiian Islands (MHI). We reveal these regional patterns through fisher "creel" surveys conducted by local communities, state agencies, academics, and/or environmental organizations, at 18 sites, comprising $>10,000 \mathrm{hr}$ of monitoring across a range of habitats and human influences throughout the MHI. All creel surveys included in this study except for one were previously published in some form (peer-reviewed articles or gray literature reports). Here, we synthesize these studies to document spatial patterns in nearshore fisheries catch, effort, catch rates (i.e., catch-per-uniteffort [CPUE]), and catch disposition (i.e., use of fish after catch is landed). This effort provides for a description of general regional patterns based on these location-specific studies. Line fishing was by far the dominant gear type employed. The most efficient gear (i.e., highest CPUE) was spear $\left(0.64 \mathrm{~kg} \mathrm{hr}^{-1}\right)$, followed closely by net $\left(0.61 \mathrm{~kg} \mathrm{hr}^{-1}\right)$, with CPUE for line $\left(0.16 \mathrm{~kg} \mathrm{hr}^{-1}\right)$ substantially lower than the other two methods. Creel surveys also documented illegal fishing activity across the studied locations, although these activities were not consistent across sites. Overall, most of the catch was not sold, but rather retained for home consumption or given away to extended family, which suggests that cultural practices and food security may be stronger drivers of fishing effort than commercial exploitation for coral reef fisheries in Hawai ' $\mathrm{i}$. Increased monitoring of spatial patterns in nearshore fisheries can inform targeted management, 
48 and can help communities develop a more informed understanding of the drivers of marine

49 resource harvest and the state of the resources, in order to maintain these fisheries for food 50 security, cultural practices, and ecological value. 
52

53

54

55

56

57

58

\section{Introduction:}

Fisheries contribute $20 \%$ of the protein for $>3$ billion people and $17 \%$ of global protein consumed, representing a crucial contribution to global food security (UN FAO, 2016). In the tropics, coral reef fisheries support $>6$ million reef fishers in over 100 countries, providing critical and diverse services, including food, income, livelihoods, and cultural significance (Teh, Teh \& Sumaila, 2013). Nowhere are coral reef fisheries more important than in the developing economies and communities in the Pacific (Dalzell, 1996; Gillett, 2016). In Hawai' $i$, these fisheries are relied upon for economic, social, and cultural services, including important livelihood and food provisioning (Friedlander, Shackeroff \& Kittinger, 2013). Approximately a third of Hawai'i residents identify themselves as fishers, and the diversity of cultures that live in Hawai'i all place a high importance on fishing (OmniTrak, 2011).

Despite their importance, many small-scale reef fisheries, both commercial and noncommercial, in the Pacific have significant capacity gaps in management, threatening the food security and livelihoods that these fisheries provide to communities (Newton et al., 2007; Bell et al., 2009; Kronen et al., 2010a,b; Houk et al., 2012; Friedlander, Nowlis \& Koike, 2014). Many of the challenges currently hindering sustainable management and fisheries sector development strategies are associated with a lack of information for these multi-species, multi-gear smallscale coral reef fisheries (Cinner et al., 2012; Fenner, 2012).

One of the most persistent knowledge gaps for scientists and managers surrounds the dominant harvesting modes and magnitude of current fishing activities, including the total production of the fishery and its value to local communities and economies. This gap is largely due to a lack of assessments of fishing activities and fish stocks, a challenge that is common in un-assessed or otherwise data-poor fisheries, which account for more than $80 \%$ of the global 
fisheries catch (Dalzell, 1996; Sale, 2008; Costello, Wilson \& Houlding, 2012; Ricard et al., 2012; Friedlander, 2015). The lack of investment in monitoring is primarily due to low technical and financial capacity in many coral reef geographies, as well as the complexity of these smallscale fisheries, which precludes an accurate understanding of fisheries status, which is required to develop effective, evidence-based regulations (Pauly, 2006; Zeller et al., 2006; Pauly \& Zeller, 2014).

To develop better management strategies, scientists and managers need more accurate estimates of how much fish biomass is in the water, how much is being fished, what fishing gears are used, and whether the rates and amount of catch are ecologically sustainable. A variety of methods have been advanced to address this gap (Nadon et al., 2015; Prince et al., 2015; Anderson et al., 2017; Nadon, 2017; Rosenberg et al., 2017), but the data necessary to accomplish these assessments remain a major limitation. An empirical method for fisheries assessment that has worked effectively at local community scales is the creel survey approach, which focuses on estimating total catch, gear types used, selectivity of gear types (i.e., variety in targeted species), and other aspects of fishing behavior (Malvestuto, 1983). Creel surveys, utilizing estimates of fishing effort paired with fisher interviews, have been particularly useful in assessing the nearshore fisheries and total economic value to local communities in several locations in the Pacific (Albert et al., 2015a,b; Weijerman et al., 2016), and particularly in Hawai'i (Friedlander \& Parrish, 1997; Everson \& Friedlander, 2004; Kittinger et al., 2015). The name creel survey comes from the woven basket, or creel, that freshwater anglers use to hold their catch (Malvestuto, 1996). In Hawai'i, these surveys are referred to by the Hawaiian name for a tin basin used to hold nets called a pakini (Kittinger et al., 2015). Surveys are typically conducted at access points where fishers are asked about their fishing activities. This approach is 
98

99

100

101

102

103

104

105

106

107

108

109

110

111

112

113

114

115

generally more effective than studies that do not engage the local community, because the information gathered stems from the fishers themselves (Whyte, Greenwood \& Lazes, 1989;

Scholz et al., 2004; Kittinger, 2013). Some creel surveys, especially for more recent survey efforts, have been led by communities, in a 'co-design' format. Creel surveys offer tremendous advantages in terms of accuracy at a particular location. However, they are resource-intensive to implement, and are therefore often limited in their spatial and temporal scope, precluding researchers, managers, and communities from recognizing larger-scale trends necessary for managing targeted fish stocks in reef fisheries (Weijerman et al., 2016).

The purpose of our study was to gather, collate, and synthesize with unparalleled geographical coverage and detail, a clearer picture of the reef-associated fishing effort, catch, CPUE, and fate of the reef catch at a regional-scale, using a unique dataset and case study approach in Hawai ${ }^{`} i$. This work addresses long-standing interest in information about coastal fisheries in Hawai'i and similar coral reef geographies, which have remained poorly quantified, particularly in terms of non-commercial fishing effort and catch. The patterns found here are determined through, arguably, the most accurate and high-resolution methodology; through fisher surveys conducted at 18 sites across the archipelago. This broad regional coverage provides unique insights into the current state of nearshore fishing effort and catch, and demonstrates the value of creel surveys as a community-level monitoring technique producing information critical to effective fisheries management by assessing distinct spatial patterns in: (1) gear usage; (2) annual catch; and (3) disposition of the catch.

\section{Methods:}

\section{Study sites:}


Kaua' $^{\prime}$, and only 7,345 people on Molokai (State of Hawai'i, 2010). Wave energy varies activity is at its highest (Stamoulis \& Friedlander, 2013). not capture the full extent of fishing catch and effort due to the non-commercial nature of these fisheries, which unlike commercial catch is not required to be reported, and the disparate landing sites across the state (Smith, 1993; McCoy et al., in review). To address this issue, we complied a large database of creel surveys conducted at 18 sites, across several islands, and over three decades. Details on the compiled information from creel surveys for fishing effort, catch, CPUE, fish flows (i.e., catch disposition), and illegal fishing (e.g., use of illegal gear, take of undersized regulated species, fishing in restricted areas) for the MHI and reported values are presented in the were previously published in some form (peer-reviewed articles or gray literature reports) except the data for Kaloko-Honokōhau National Historical Park, Hawai'‘i Island, which came from intercept interview data (i.e., interview data with fishers), from which we produced estimates of effort, catch, and CPUE that are described in S1. and/or fish flow survey was conducted at the site in the MHI. Second, we had access to a report, 
144 publication, and/or the raw data. Thirdly, for creel surveys, the monitoring effort had to be 145 conducted for longer than one month. Lastly, that the study met data quality standards based on 146 prior knowledge by the authors in consultation with other local authorities. Sample sites included 147 urban and major tourist destinations, such as Maunalua Bay, Pearl Harbor, and Waikīkī on 148 O`ahu, as well as Wailuku on Maui, which we expected to be characterized by high level of 149 fishing effort but low catch based on anecdotal evidence. Conversely, remote rural communities 150 such as Kalaupapa National Historical Park on Moloka'i, and Hā'ena on Kaua‘i, were expected 151 to have higher catch rates but lower overall effort (Fig. 1). Puakō on Hawai'i Island was

152 surveyed from May 1980 to September 1981, and again from December 2008 to December 2009

153 (Table 1). For patterns in fishing gear, we used data from all 18 locations. Examination of fishing 154 effort and total catch had 14 available datasets, with 13 for CPUE, and 8 for fish flow (Table 1). 


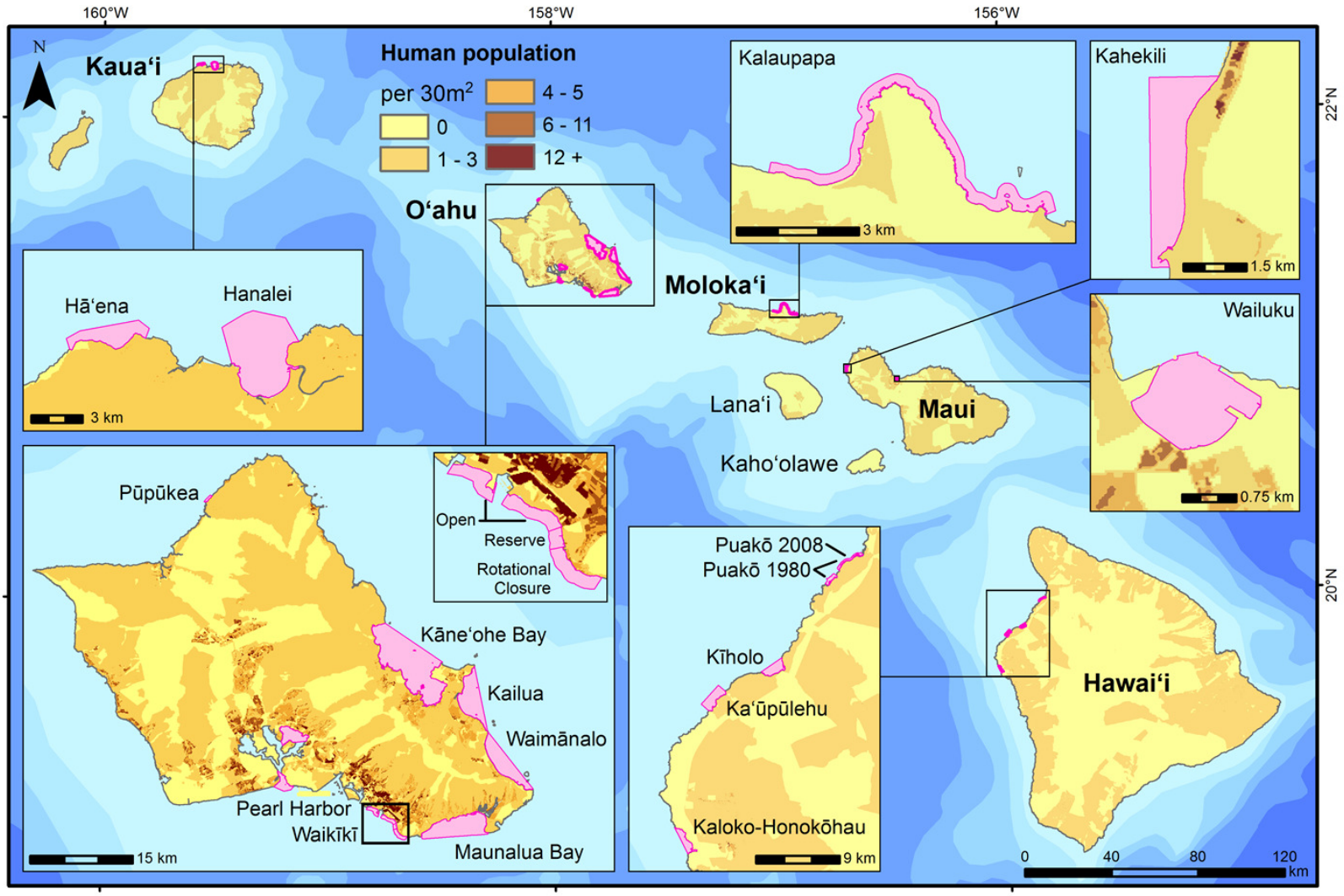

156

157 Figure 1. Survey sites where creel and/or fish flow surveys were conducted and included in this

158 study are shown in pink. 2010 human population (State of Hawai‘ ${ }^{1}, 2010$ ) is distributed based on

159 land cover types within census blocks. 
161 Table 1. Location, availability of data, and its inclusion in analyses of gear most commonly used, effort, catch,

162 CPUE estimates, and/or fish flows and the source for this information. " 0 " indicates the information was not

163 available and " 1 " indicates the information was available.

Most popular
gear Effort Catch CPUE Fish flow Source

\begin{tabular}{|c|c|c|c|c|c|c|}
\hline Hā‘ena, Kaua‘i & 1 & 0 & 0 & 1 & 1 & $\begin{array}{l}\text { Vaughan \& Vitousek, 2013; Kua‘āina Ulu } \\
\text { ‘Auamo (KUA), Hui Maka‘āinana o Makana } \\
\text { and Limahuli Gardens staff, unpub. report; } \\
\text { McCoy et al., in review }\end{array}$ \\
\hline Hanalei, Kaua'i & 1 & 1 & 1 & 1 & 1 & $\begin{array}{c}\text { Friedlander \& Parrish, 1997; Everson \& } \\
\text { Friedlander, 2004; Glazier \& Kittinger, } 2012\end{array}$ \\
\hline Kahekili, Maui & 1 & 1 & 1 & 1 & 0 & Friedlander et al., 2012 \\
\hline Kailua, O`ahu & 1 & 1 & 0 & 0 & 0 & Friedlander et al., 2014a \\
\hline Kalaupapa, Moloka'i & 1 & 0 & 0 & 0 & 0 & Tom, 2011 \\
\hline Kaloko-Honokōhau, Hawai‘i & 1 & 1 & 1 & 1 & 0 & K. Tom and J. Beets unpub. data \\
\hline Kāne‘ohe Bay, O‘ahu & 1 & 1 & 1 & 1 & 1 & Everson \& Friedlander, 2004 \\
\hline Ka'ūpūlehu, Hawai'i $i$ & 1 & 1 & 1 & 1 & 0 & Koike et al., 2015 \\
\hline Kīholo, Hawai'i & 1 & 1 & 1 & 1 & 1 & Kittinger et al., 2015 \\
\hline Maunalua Bay, O`ahu & 1 & 1 & 1 & 1 & 1 & Kittinger, 2013, McCoy et al., in review \\
\hline Pearl Harbor, $\mathrm{O}^{`} \mathrm{ahu}$ & 1 & 1 & 1 & 1 & 0 & Wolfe et al., 2017 \\
\hline $\begin{array}{l}\text { Puakō, Hawai‘i } \\
(1980-1981)\end{array}$ & 1 & 1 & 1 & 1 & 0 & Hayes et al., 1982 \\
\hline Puakō, Hawai'i (2008-2009) & 1 & 1 & 1 & 1 & 1 & Giddens, 2010; J. Giddens pers. comm. \\
\hline Pūpūkea, O`ahu & 1 & 1 & 0 & 0 & 0 & Stamoulis \& Friedlander, 2013 \\
\hline Waikīkī reserve, O'ahu & 1 & 0 & 1 & 0 & 0 & Meyer, 2003 \\
\hline Waikīkī open, O`ahu & 1 & 0 & 1 & $1^{*}$ & 0 & Meyer, 2003 \\
\hline $\begin{array}{l}\text { Waikīkī rotational closure } \\
\text { area, } \mathrm{O}^{\prime} \text { ahu }\end{array}$ & 1 & 0 & 1 & 0 & 0 & Meyer, 2003 \\
\hline Wailuku, Maui & 1 & 1 & 1 & 1 & 1 & $\begin{array}{c}\text { Koike, Carpio \& Friedlander, 2014, Koike } \\
\text { pers. comm. }\end{array}$ \\
\hline Waimānalo, O‘ahu & 1 & 1 & 0 & 0 & 0 & $\begin{array}{l}\text { Friedlander et al., 2014a; K. Stamoulis pers. } \\
\text { comm. }\end{array}$ \\
\hline Hawai‘i Island, Hawai`i & 0 & 0 & 0 & 0 & 1 & Hardt, 2011 \\
\hline
\end{tabular}

$164{ }^{*}$ The CPUE estimates for Waikīkī were not reported for the 3 individual sites separately. 


\section{Creel survey methodology:}

Creel surveys in Hawai'i have typically quantified fishing effort using interviews and/or

167

168

169

170

171

172

173

174

175

176

177

178

179

180

181

182

183

184

185

186

187

elevated vantage points, where observers scanned the area on a systematic schedule using binoculars and/or high-power spotting telescopes (Friedlander \& Parrish, 1997; Tom, 2011;

Friedlander et al., 2014a). Interview-based surveys are conducted using access point and roving survey methods. An access point survey targets a specific site that generally has a single pathway where fishers can be sampled upon completion of a fishing trip (e.g., piers, jetties, or a remote beach with one entry point [Robson \& Jones, 1989]). A roving survey targets a broader area where access is generally undefined and fishers are more dispersed (Malvestuto, Davies \& Shelton, 1978; Malvestuto, 1996). It is conducted by walking and/or driving along a stretch of coastline and stopping when a fisher is located for a potential interview (Malvestuto, Davies \& Shelton, 1978; Pollock et al., 1997). Interviews were typically conducted with fishers to gather information such as catch and species composition. Estimates of total annual catch were obtained by multiplying effort for each gear type with the corresponding CPUE and expanded based on a stratified random survey design (references in Table 1 or S1).

Our assessment was focused on patterns in nearshore fishing by compiling estimates from previously conducted creel surveys to produce regional maps of total annual catch, CPUE, and effort for the three dominant nearshore gear types: shore-based line, net, and spear. These broad categories of gear are the most common and popular types of fishing methods in Hawai'i. We created boundary polygons using ArcGIS 10.4 based on maps and description of surveyed areas in each creel study. These polygons represent the marine area surveyed and were delineated based on the National Oceanic and Atmospheric Administration (NOAA) Biogeography Branch shoreline data for the MHI (Battista, Costa \& Anderson, 2007). Total area in $\mathrm{km}^{2}$ for each creel 
188 survey area polygon was calculated in ArcGIS, as well as area of coral reef and hard bottom as 189 delineated by Battista et al. (2007). Length of shoreline for each creel area was measured after 190 first simplifying creel polygon features to standardize measurements using the ArcGIS Simplify 191 Polygon tool with a maximum allowable offset of $100 \mathrm{~m}$, which removed extraneous bends 192 while preserving the essential shape (Table 2; ESRI, 2011). 
193 Table 2. Location, start and end dates of surveys, coastline length, total area, and area of coral 194 reef and hard bottom in creel survey sites as delineated by Battista et al. (2007). Surveys were 195 conducted from 1980 to 2016.

\begin{tabular}{|c|c|c|c|c|}
\hline Location & $\begin{array}{l}\text { Start and end } \\
\text { dates }\end{array}$ & $\begin{array}{l}\text { Coastline } \\
(\mathrm{km})\end{array}$ & $\begin{array}{l}\text { Total Area } \\
\left(\mathrm{km}^{2}\right)\end{array}$ & $\begin{array}{l}\text { Area of coral } \\
\text { reef and hard } \\
\text { bottom }\left(\mathrm{km}^{2}\right)\end{array}$ \\
\hline Hā'ena, Kaua'i & Aug 09-Dec 10 & 3.6 & 2.05 & 1.25 \\
\hline Hanalei, Kaua'i & Jul 92-Dec 93 & 6.2 & 7.58 & 2.82 \\
\hline Kahekili, Maui & Jan 11-Dec 11 & 3.6 & 1.88 & 0.46 \\
\hline Kailua, O`ahu & Jan 08-Aug 13 & 11.8 & 14.84 & 12.55 \\
\hline Kalaupapa, Moloka'i & Aug 08-Nov 10 & 19.6 & 7.41 & 3.08 \\
\hline Kaloko-Honokōhau, Hawai‘i & Jan 10-Jan 11 & 6.0 & 2.26 & 1.62 \\
\hline Kāne'ohe Bay, O’ahu & $\begin{array}{l}\text { Spring 91- } \\
\text { Spring } 92\end{array}$ & 33.7 & 48.46 & 23.97 \\
\hline Ka'ūpūlehu, Hawai'i & Aug 13-Aug 14 & 3.7 & 3.53 & 2.13 \\
\hline Kīholo, Hawai'i & May 12-Apr 13 & 4.5 & 2.65 & 1.77 \\
\hline Maunalua Bay, O`ahu & $\begin{array}{l}\text { Dec } 07-\text { Nov } \\
08^{*} \text { and Jan } 11- \\
\text { Jul } 11^{\#}\end{array}$ & 15.1 & 19.12 & 16.11 \\
\hline Pearl Harbor, O`ahu & Jun 15-May 16 & 14.9 & 8.06 & 1.96 \\
\hline Puakō, Hawai`i (1980-1981) & May 80-Sep 81 & 6.6 & 1.43 & 1.27 \\
\hline Puakō, Hawai‘i (2008-2009) & Dec 08-Dec 09 & 4.9 & 0.85 & 0.75 \\
\hline Pūpūkea, O`ahu & Jun 11-Sep 11 & 1.2 & 0.31 & 0.30 \\
\hline Waikīkī reserve, O`ahu & Jun 98-Aug 01 & 0.7 & 0.31 & 0.28 \\
\hline Waikīkī open, O`ahu & Jun 98-Aug 01 & 4.8 & 1.80 & 1.41 \\
\hline $\begin{array}{l}\text { Waikīkī rotational closure } \\
\text { area, } \mathrm{O}^{`} \text { ahu }\end{array}$ & Jun 98-Aug 01 & 1.9 & 0.97 & 0.84 \\
\hline Wailuku, Maui & Mar 13-May 14 & 3.3 & 0.93 & 0.16 \\
\hline Waimānalo, O`ahu & Jan 08-Aug 13 & 11.4 & 14.22 & 6.15 \\
\hline
\end{tabular}

Fish flow surveys: main drivers of fishing (e.g., commerce, recreation, subsistence, culture). To accomplish this, we 
201 obtained information on fish flow across the MHI. This information included the distribution of

202 catch, and whether it was: 1) kept for home consumption; 2) given away; 3) sold (or bartered); 4)

203 released; 5) used as bait and/or 6); used for other purposes (Hardt, 2011; Kittinger, 2013;

204 Kittinger et al., 2015). Fish flow information estimates how catch from nearshore marine

205 ecosystems is used by local fishers and the role it has in local economies and households (Glazier

206 \& Kittinger, 2012; Kittinger, 2013).

207

208 Results:

209

Patterns in effort, catch and CPUE from creel surveys:

210

Line fishing was the most commonly employed gear type at all the sites except for one

211 (94\% of the sites; Table 3), with net fishing (primarily cast nets) being most commonly used at

212

Hā'ena, Kaua' $i$ (surveyed 2009-2010) (6\% of the sites; Table 3). In all cases where the estimate

213

of fishing effort was quantified in hours, line fishing had the highest estimate of effort (Table 3).

214

On average, line fishing was almost $80 \%$ of the total shore fishing effort with only $7 \%$ and $14 \%$

215 from net and spear fishing, respectively. However, the most efficient gear types (i.e., highest

216 CPUE) were spear $\left(\bar{X}=0.64 \mathrm{~kg} \mathrm{hr}^{-1} ; \mathrm{SE}=0.12\right)$, followed closely by net $\left(\bar{X}=0.61 \mathrm{~kg} \mathrm{hr}^{-1} ; \mathrm{SE}=\right.$

217 0.19), with CPUE for line $\left(\bar{X}=0.16 \mathrm{~kg} \mathrm{hr}^{-1} ; \mathrm{SE}=0.04\right) 3.9$ times lower than spear and 3.7 times

218 lower than net (Table 4). 
221 Table 3. Location, most commonly used fishing gear type ("gear": gear with highest frequency

222 of occurrence or density of fishing activities by gear type), estimates of effort for three shore-

223 based fishing gear types (hr), total annual catch $(\mathrm{kg})$, percent of total catch that is biomass of

224 Selar crumenophthalmus ("scad"), and octopus (Octopus cyanea and Callistoctopus ornatus).

225 The two species were included since at some sites they compose a large portion of the total

226 harvest. Some values were not available (“-"). Details for derivations of these values are

227 provided in $\mathrm{S} 1$.

\begin{tabular}{|c|c|c|c|c|c|c|c|}
\hline Location & Gear & Line & Net & Spear & Catch & $\%$ Scad & \% Octopus \\
\hline Hā'ena, Kaua'i & Net & - & - & - & - & - & - \\
\hline Hanalei, Kaua'i & Line & 15,850 & 5,370 & 397 & 15,801 & 39.4 & - \\
\hline Kahekili, Maui & Line & 3,925 & 108 & 2,857 & 1,214 & - & 36.6 \\
\hline Kailua, O`ahu & Line & 3,867 & 106 & 2,184 & - & - & - \\
\hline Kalaupapa, Moloka‘i & Line & - & - & - & - & - & - \\
\hline Kaloko-Honokōhau, Hawai' i & Line & 4,538 & 208 & 2,331 & 3,277 & 0.0 & 5.9 \\
\hline Kāne‘ohe Bay, O‘ahu & Line & 35,748 & 5,711 & 15,926 & 63,958 & 1.6 & 21.3 \\
\hline Ka'ūpūlehu, Hawai'i & Line & 5,089 & 1,319 & 4,587 & 4,599 & 1.2 & 12.2 \\
\hline Kīholo, Hawai‘i & Line & 5,004 & 1,580 & 799 & 7,353 & - & - \\
\hline Maunalua Bay, O`ahu & Line & 16,441 & 888 & 4,099 & 5,543 & - & - \\
\hline Pearl Harbor, $\mathrm{O}^{`}$ ahu & Line & 98,725 & 698 & 927 & 7,726 & 0.0 & 2.4 \\
\hline Puakō, Hawai‘i (1980-1981) & Line & 5,017 & - & 1,962 & 8,063 & 0.0 & 2.7 \\
\hline Puakō, Hawai‘i (2008-2009) & Line & 2,917 & 1,239 & 1,958 & 2,323 & 0.0 & - \\
\hline Pūpūkea, O`ahu & Line & 3,685 & 5 & 1,511 & - & - & - \\
\hline Waikīkī reserve, O‘ahu & Line & - & - & - & 28 & - & - \\
\hline Waikīkī open, O‘ahu & Line & - & - & - & 457 & - & - \\
\hline $\begin{array}{l}\text { Waikīkì rotational closure, } \\
\mathrm{O}^{`} \mathrm{ahu}\end{array}$ & Line & - & - & - & 581 & - & - \\
\hline Wailuku, Maui & Line & 15,701 & 2,192 & 719 & 2,161 & 6.3 & 3.1 \\
\hline Waimānalo, O‘ahu & Line & 7,140 & 11 & 317 & - & - & - \\
\hline
\end{tabular}


230 Table 4. Catch-per-unit-effort (CPUE) estimates in $\mathrm{kg} \mathrm{hr}^{-1}$ for three shore-based fishing gear

231 types (line, net, and spear fishing). Some values were not available (“-”). Details for derivations

232 of these values are provided in S1.

\begin{tabular}{|c|c|c|c|}
\hline Location & Line & Net & Spear \\
\hline Hā‘ena, Kaua‘i & 0.09 & 0.43 & 0.56 \\
\hline Hanalei, Kaua'i & 0.07 & 0.96 & 0.87 \\
\hline Kahekili, Maui & 0.09 & 0.03 & 0.30 \\
\hline Kailua, O`ahu & - & - & - \\
\hline Kalaupapa, Moloka‘i & - & - & - \\
\hline Kaloko-Honokōhau, Hawai'i & 0.01 & 0.07 & 0.67 \\
\hline Kāne'ohe Bay, O’ahu & 0.27 & 0.87 & 0.93 \\
\hline Ka‘ūpūlehu, Hawai`i & 0.23 & 0.39 & 0.51 \\
\hline Kîholo, Hawai'i & 0.62 & 1.81 & 1.79 \\
\hline Maunalua Bay, O‘ahu & 0.10 & 0.11 & 0.23 \\
\hline Pearl Harbor, O`ahu & 0.06 & - & 0.42 \\
\hline Puakō, Hawai‘i (1980-1981) & 0.28 & - & 0.48 \\
\hline Puakō, Hawai‘i (2008-2009) & 0.15 & 1.27 & 0.23 \\
\hline Pūpūkea, O`ahu & - & - & - \\
\hline Waikīkī, O’ahu & 0.04 & - & 1.13 \\
\hline Wailuku, Maui & 0.12 & 0.14 & 0.22 \\
\hline Waimānalo, O‘ahu & - & - & - \\
\hline
\end{tabular}

233

Fishing effort estimates varied within and across the MHI. The highest estimates of effort

235 were on $\mathrm{O}^{\prime}$ ahu, which is the most populated island in the state (Figs. 1 and 2). The highest estimate of fishing effort was recorded at Pearl Harbor (surveyed 2015-2016), a denselypopulated embayment in urban Honolulu, with $>100,000 \mathrm{hr}$ of non-vessel-based fishing effort, nearly all of which was line fishing (Fig. 2; Table 3). Kāne‘ohe Bay (surveyed 1991-1992) is a

239 large, sheltered bay on windward $\mathrm{O}^{`}$ ahu and had the second highest total effort among all 240 locations (Fig. 2; Table 3). Effort estimates across O`ahu were extremely variable, with the 241 lowest overall fishing effort observed at Pūpūkea (surveyed 6/2011-9/2011), on the relatively 
242 less populated north shore (Figs. 1 and 2). Fishing effort was generally lower at less populated 243 parts of the MHI (Figs. 1 and 2).

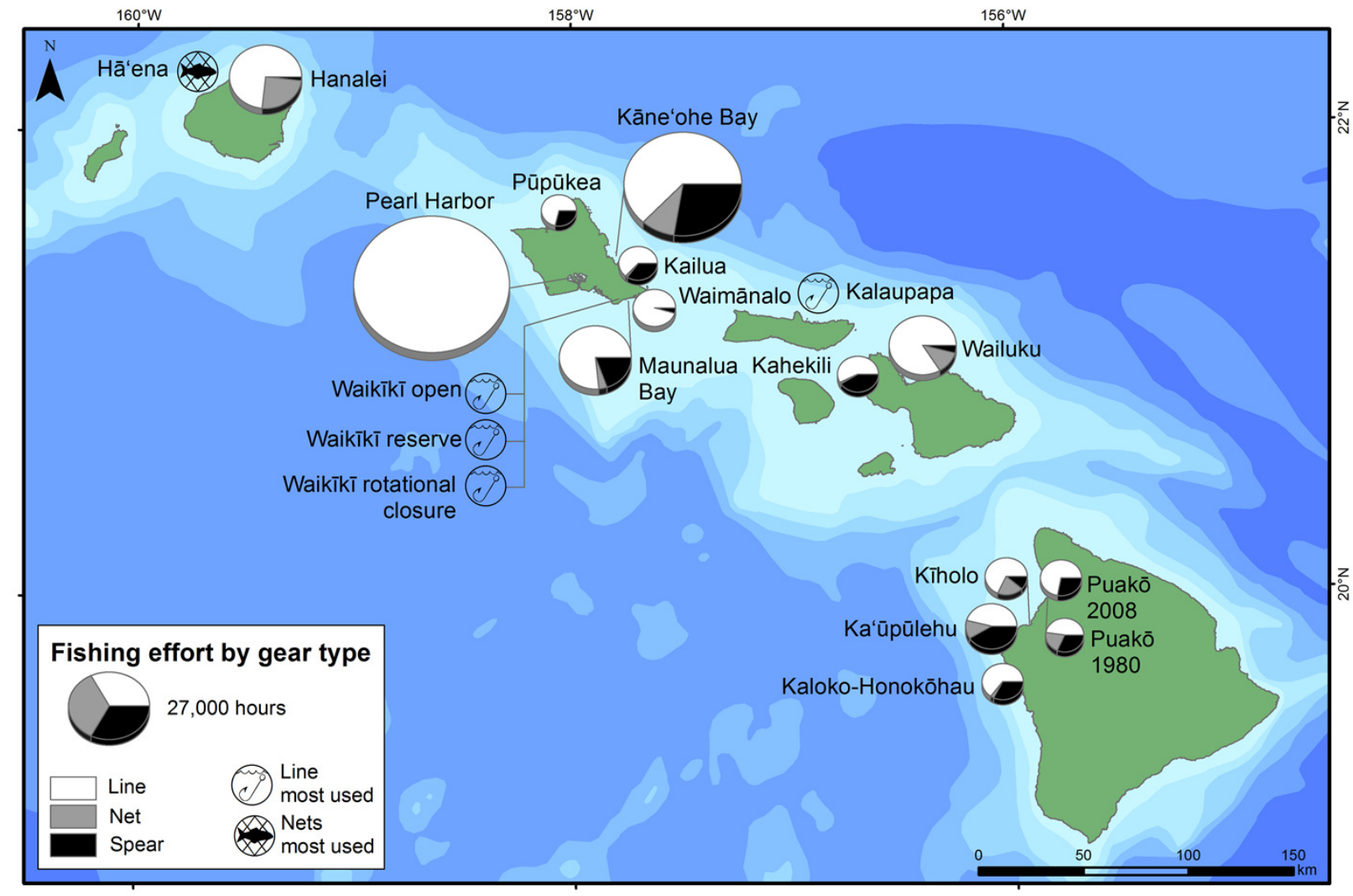

244

245 Figure 2. Shore-based fishing effort by gear type. Pie sizes are scaled to represent annualized

246 estimates of total fishing effort by shore-based line, net, and spear fishing activities at each site.

247 If annualized estimates of effort hours were not quantified for the gear types but the survey

248 reported the most commonly used gear type (e.g., gear with highest frequency of occurrence or

249 density of fishing activities by gear type), a symbol indicating the most commonly used gear was

250 added to the map to document this gear preference. 


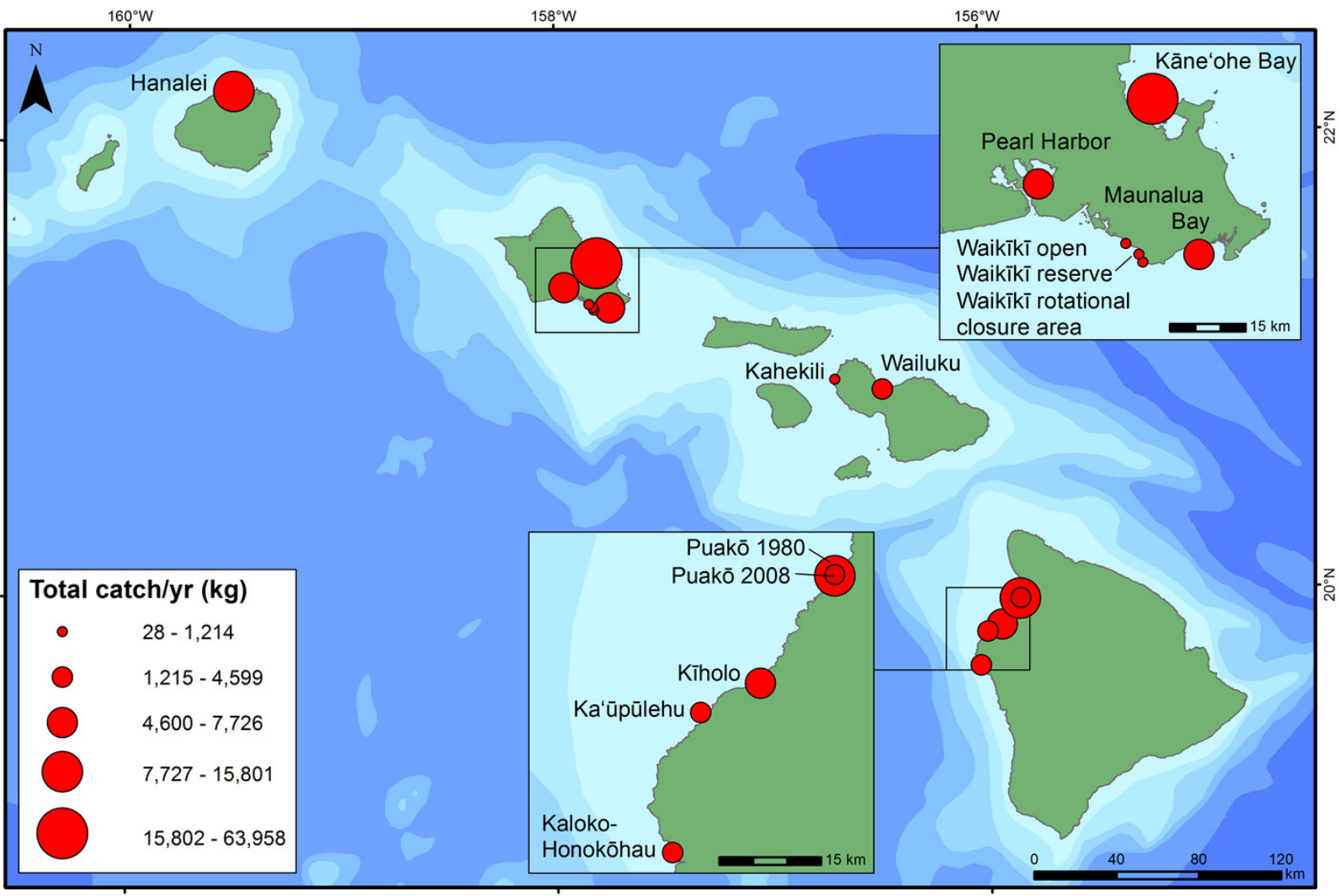

252

253 Figure 3. Total catch per year $(\mathrm{kg})$ at each site. Circles scaled to represent total annual fisheries and invertebrate harvest at that site. and/or tourist-dominated sites such as Waikīkī (surveyed 1998-2001), Pearl Harbor (surveyed 2015-2016), and Maunalua Bay (surveyed 2007-2008) on O`ahu, as well as Kahekili (surveyed 1/2011-12/2011) and Wailuku (surveyed 2013-2014) on Maui. Catches were similar for the four survey sites along the west coast of Hawai'i Island (Fig. 3). A large proportion of total catch was reported to be composed of small coastal pelagic species (primarily Selar crumenophthalmus) or octopus (Octopus cyanea and Callistoctopus ornatus) at a few sites (Table 3). Octopus accounted 
264 for 21.3\% of the catch in Kāne'ohe Bay (surveyed 1991-1992), and 36.6\% at Kahekili (surveyed

265 1/2011-12/2011) (Table 3). Hanalei Bay (surveyed 1992-1993) on Kaua'i, which had the second

266 largest annual catch, almost $40 \%$ of the catch biomass consisted of a small coastal pelagic

267 species, S. crumenophthalmus that were almost all caught in nets. At Puakō, annual fisheries

268 harvest decreased from 1980-1981 to 2008-2009 (Fig. 3). The size of the more recent creel

269 survey at Puakō is 59\% of the area of the older survey area, but the catch of the new survey was

270 estimated to be only $29 \%$ of the total annual catch of the previous survey. In the $1980-1981$

271 survey of Puakō, the three species with the highest harvested biomass were acute-jawed mullet

272 (Neomyxus leuciscus), convict tangs (Acanthurus triostegus), and blackspot sergeant (Abudefduf

273 sordidus). In the 2008-2009 survey at this site, the top three species harvested were convict tangs

274 (Acanthurus triostegus), spotted surgeonfish (Ctenochaetus strigosus), and rudderfishes

275 (Kyphosus spp.).

276 CPUE estimates were generally lower in more urban and/or touristic locations, as

277 expected (e.g., O`ahu, and Kahekili [surveyed 1/2011-12/2011] and Wailuku [surveyed 2013-

278 2014] on Maui). Conversely, these estimates were generally higher at less densely population

279 places, such as Hā'ena (surveyed 2009-2010) and Hanalei (surveyed 1992-1993) on Kaua‘i, and

280 Kîholo (surveyed 2012-2013) on the island of Hawai'i, with the exception of high spear CPUE at

281 Waikīkī (surveyed 1998-2001) (Fig. 4; Table 4). CPUE estimates were relatively high at

282 Kāne'ohe Bay (surveyed 1991-1992), which could be due to the earlier time period and because

283 line fishing CPUE estimates were combined for shore and boat-based activities. At Puakō, CPUE

284 estimates decreased from 1980-1981 to 2008-2009 for both line and spear fishing by 46.4\% and

$28552.1 \%$, respectively (Table 3). Line fishing was almost always the least effective gear type (Fig.

286 4). Illegal fishing was reported at least nine of the survey locations. Violations at sites ranged 
287 from harvested undersized fish, use of illegal gears, take of prohibited species, and fishing in off-

288 limit areas (Table 5).

290 Table 5. Location and examples of the reported illegal fishing activity reported at survey sites.

\section{Location and survey period}

Hanalei, Kaua'i

(surveyed 1991-1992)

Kahekili, Maui

(surveyed 1/2011-12/2011)

Kailua, O`ahu

(surveyed 2008-2013)

Pearl Harbor, O`ahu

(surveyed 2015-2016)

Puakō, Hawai‘i

(surveyed 2008-2009)

Pūpūkea, O`ahu

(surveyed 6/2011-9/2011)

Waikīkī reserve and boundary

areas of the reserve

(surveyed 1998-2001)

Wailuku, Maui

(surveyed 2013-2014)

\section{Type of activity}

More than $70 \%$ of all the juvenile jacks (Carangidae) caught were below the minimum legal size

At the Kahekili Herbivore Management Area there was illegal take of herbivorous fishes

Illegal gill net activities were detected in 2008 and 2012

Spearfishing and net fishing were documented in areas where these gear types were not allowed, as well as the catch of undersized species, primarily small jacks

Many of the convict tangs (Acanthurus triostegus), parrotfishes (Scaridae) and jacks (Carangidae) that were retained were smaller than the minimum legal size

An average of 27 fishers per week illegally fish in the Pūpūkea-Waimea marine reserve

Dozens of illegal spear, and pole and line fishing events were observed in the Waikīki reserve

$33 \%$ of the fishing activity recorded was illegal and included exceeding daily allowance for marine life and using nets that were illegal size or permitted type 


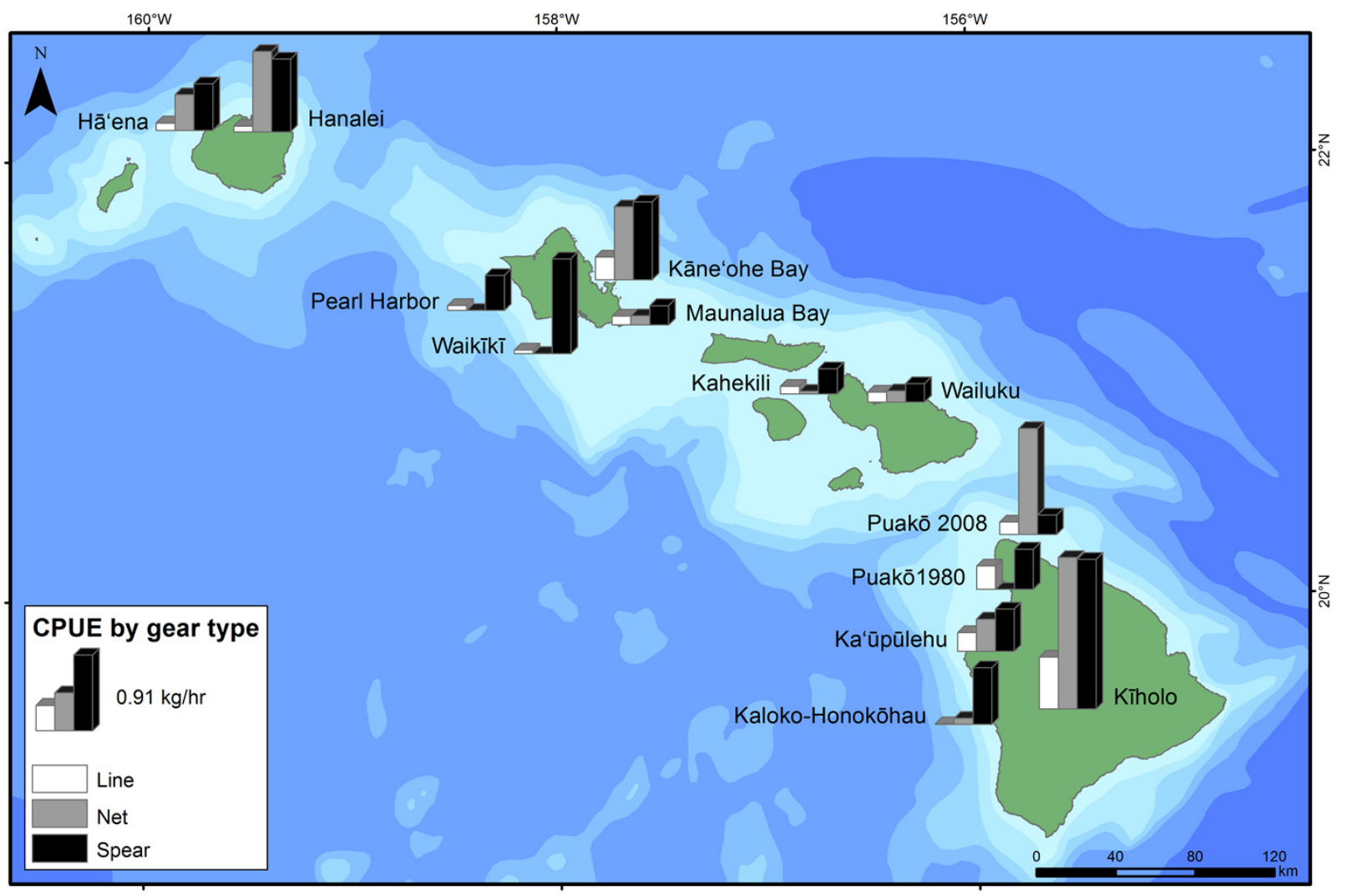

291

292 Figure 4. Catch-per-unit-effort (CPUE - $\mathrm{kg} \mathrm{hr}^{-1}$ ) for the three dominant shore-based fishing gears 293 (line, net, and spear) by survey location. 
295

296

297 (Fig. 5). Negligible proportions of the catch were reported as sold (Fig. 5). At Wailuku (surveyed

298 2013-2014), Maui, $>40 \%$ of the catch was released, reportedly due to fish being undersized.

299 While all the fish flow surveys quantified the proportion of fish and invertebrate biomass kept, 300

301

302

303

304

305

\section{Patterns in Fish Flows:}

The majority of the fish caught was either kept or given away for home consumption not all surveys (e.g., Wailuku) quantified the proportion of catch that was sold. Additionally, some of the fish flow categories varied among survey locations. For example, the survey of Wailuku (surveyed 2013-2014) only reported the categories of catch that were kept and released and for surveys conducted at Hā'ena (surveyed 2009-2010) and Puakō (surveyed 2008-2009), catch used as bait was quantified separately. 


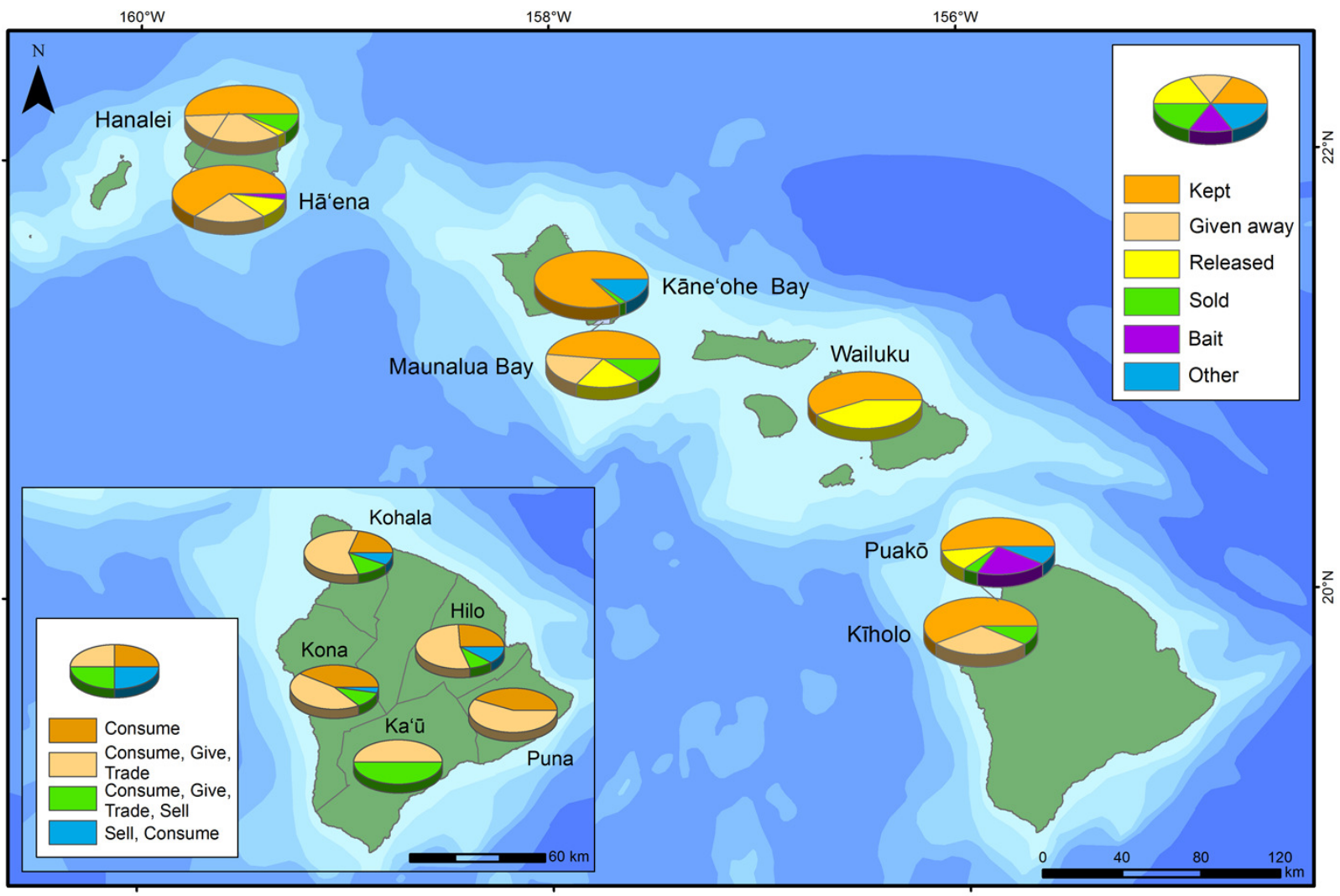

306

307 Figure 5. Fish flow for each survey location. Disposition of catch: kept, given away, used as bait,

308 other, released and/or sold. In the lower left inset, data from Hardt (2011) on fish flows were

309 included.

\section{Discussion:}

creel surveys reveals important insights into the characteristics of coral reef fisheries in

314 unprecedented detail. The compiled surveys comprised $>10,000 \mathrm{hr}$ of monitoring across a

315 diverse set of locations, with participation from local communities, state agencies, academics, and non-profit organizations. Below, we discuss the implications of our findings for managing 
317 these complex coral reef fisheries, focusing on options available to managers to support

318 increased ecosystem production and resilience.

\section{Management options for rebuilding coral reef fisheries:}

There are several ways to assess the sustainability of reef fisheries. While a range of yield

321

322

323

324

325

326

327

328

329

estimates for sustainable harvest have been proposed for coral reefs (Stevenson \& Marshall, 1974; Dalzell, 1996; Newton et al., 2007; McClanahan et al., 2011), by most measures the nearshore fisheries in Hawai'i are in poor health (Friedlander \& DeMartini, 2002; Friedlander et al., 2008; Williams et al., 2008; Nadon et al., 2015; Friedlander et al., 2017). By pairing creel surveys with fish flow surveys, it is possible to assess human use patterns and drivers of behavior in nearshore fisheries in greater detail, as well as the extent of fisheries benefits to communities. Such information can help communities develop a more informed understanding of the drivers of marine resource harvest and the state of the resources. This, in turn, helps inform effective, sustainable community-based fisheries management.

\section{Managers have the difficult task of addressing multiple drivers of fishery decline in}

Hawai' $i$, in order to sustain the important sociocultural and economic values these activities provide for local communities and visitors (Cesar \& Van Beukering, 2004; OmniTrak, 2011). In order to manage these resource systems, fisheries managers have at their disposal a range of tools that can be tailored to the specific context and challenges of a fishery to sustain, and in some cases, rebuild fisheries (Walters \& Martell, 2004; Worm et al., 2009; Hilborn \& Ovando, 2014). Many of these management tools were developed hundreds of years ago by indigenous peoples, and these strategies were particularly well developed in the Pacific Islands due to their heavy reliance on, and scarcity of these resources (Johannes, 1978). In general, these tools include input controls (which restrict effort) and output controls (which restrict catch), which are further 
340 supported by a range of technical measures (such as monitoring, assessment, and enforcement)

341 (Walters \& Martell, 2004).

\section{Output controls:}

Output controls include annual catch limits, catch size restrictions, bag limits, and other limitations on catch. Allowable catch limits have been established for coral reef fisheries in Hawai'i under federal law (WPRFMC, 2009). However, uncertainty in catch and effort data, weak to no controls on recreational and subsistence catch, limited biological information, and

347 conflicting management authorities have made these measures mostly ineffective. Bag limits (essentially fixed individual quotas) have been proposed for a number of prized target species in Hawai' $i$ and these regulations have utility in making the fishing public aware of resource limitations and the large impact from the recreational and subsistence take of these species. Although they allow the resource to be shared by many, enforcement is a major problem and these restrictions may not adequately prevent overfishing owing to the lack of accurate catch and production estimates. Their application is best suited for select species with high cultural, food, and economic value along with those fisheries that target juveniles.

Minimum size limits are a basic tenant of fisheries management, allowing fish to reach reproductive size before harvest. However, for most coral reef fisheries, setting minimum size limits is constrained by the general lack of information on size at first reproduction for many, if not most, of the species harvested. Size limits are also not effective with non-selective gear such as gillnets, and enforcement of size limits is difficult since fishes are often not sold at a central market where sizes can be regulated easily. Size limits have proven to be ineffective in centralized management of coral reef fishes due to the large number of species in the fisheries,

362 enforcement difficulties, and public awareness challenges. 


\section{Input controls:}

Advances in fishing technology (GPS, monofilament nets, scuba, etc.) have greatly

365

366

367

368

369

370

371

372

373

374

375

376

377

378

379

380

381

382

383

384

increased the efficiency of harvesting coral reef fishes in Hawai' $i$. Despite their effectiveness in

Hawai' $i$, nets and spears are used far less often than line, which means further regulation on nets

and spears could possibly reduce overall catch while not affecting the majority of fishers. Gill

nets are regulated in some areas in Hawai'i (e.g., Kailua, a large portion of the south shore of

$\mathrm{O}^{`} \mathrm{ahu}$, number of locations in West Hawai' $\mathrm{i}$, and the entire island of Maui) (Division of Aquatic

Resources, 2017). Justification for these bans was the indiscriminate catch, including juvenile

fishes, and a high bycatch of threatened and endangered species (e.g., sea turtles, marine

mammals) (Smith, 1993; Blaber et al., 2000; Donovan et al., 2016). Certain methods of spear

fishing such as nighttime and/or on scuba are highly efficient, particularly for parrotfishes, which

sleep on the reef at night and are easily harvested at that time (Richmond et al., 2002; Sabetian \&

Foale, 2006). Scuba-based spear fishing is now banned in West Hawai'i, along with many

Pacific Island nations and territories (Gillett \& Moy, 2006; Lindfield, McIlwain \& Harvey, 2014;

Division of Aquatic Resources, 2017). Despite the selective nature of spearfishing gear, it is used rather non-selectively in many cases (Fenner, 2012). Restriction on or banning of gill nets, nighttime and/or scuba-based spear fishing could potentially be quite effective and should be considered for other locations as well (McClanahan, Maina \& Davies, 2005; McClanahan \&

Cinner, 2008; Cinner et al., 2009b). Fishers are usually more supportive of gear restrictions than fisheries closures since they can often switch to another gear type (McClanahan, Maina \& Davies, 2005). In addition, gear restrictions are also preferred by fishers because they are easier to circumvent than other fisheries management strategies (Cinner et al., 2009b). 
their importance in reducing macroalgal abundance and enhancing the dominance of crustose

387

388

389

390

391

392

393

394

395

corallines, which are necessary conditions for the maintenance of healthy reef communities.

Management of herbivores (e.g., parrotfishes) has been successfully implemented on Maui with bag limit on parrotfishes and Kahekili's herbivore management area (Friedlander et al., 2012;

Williams et al., 2016; Division of Aquatic Resources, 2017). These are promising solutions that could be deployed in other geographies or at a scale to further bolster reefs against impacts of climate change. Hawai'i DAR has developed and implemented numerous output controls including size, season, and bag limit rules. However, these controls should be adapted as new knowledge emerges of the geographical variability in spawning cycles and growth characteristics of various reef fish among locations (Schemmel \& Friedlander, 2017).

\section{Technical measures:}

Marine protected areas (MPAs), have been proven to be highly successful in conserving biodiversity globally (Lubchenco et al., 2003; Lester et al., 2009), and particularly in Hawai‘i (Friedlander et al., 2003; Friedlander, Brown \& Monaco, 2007). Marine protected areas can also benefit adjacent fisheries through two primary mechanisms: increased production and export of pelagic eggs and larvae (larval spillover), and net emigration of adults and juveniles (adult spillover) (McClanahan \& Mangi, 2000; Gaines et al., 2010). Within the MHI, there are numerous state-managed areas that limit fishing activities in nearshore marine waters. Existing MPAs in Hawai' $i$ that are fully protected from fishing have higher fish biomass, larger overall fish size, and higher biodiversity than adjacent areas of similar habitat quality (Friedlander, Brown \& Monaco, 2007; Friedlander et al., 2014b). These protected areas can also benefit local fisheries, as in the case of the Pūpūkea-Waimea MPA on the north shore of O`ahu, which has 
408 resulted in significant benefit for fishers through adult spillover (Stamoulis \& Friedlander, 2013).

409 There is much resistance to the establishment of MPAs from the fishing sector for a variety of

410 reasons including: loss of fishing areas, displacement or marginalization of subsistence fishers,

411 perceived loss of income and cultural access, and the long lag time before benefits are realized

412 (McClanahan, Maina \& Davies, 2005; Cinner et al., 2009a). Although not a panacea for coral

413 reef fisheries management, MPAs in conjunction with other input and output controls are critical

414 to sustaining fisheries and maintaining ecosystem health.

415 Pacific islanders traditionally used a variety of closures that were often imposed to ensure

416 large catches for special events, or as a cache for when resources on the usual fishing grounds

417 ran low (Johannes, 1978). Traditional periodic closures can be effective for short-lived taxa that

418 reproduce quickly, but evidence across the Pacific, including Hawai' $i$, shows that taxa that are

419 long-lived and reproduce later in life do not benefit from rotational closures (Williams et al.,

420 2006). Rotational closures have been less successful in contemporary Hawai'i where there are

421 few to no controls on effort once the area is open to fishing.

\section{Customary management:}

Local fisheries management that is driven and informed by traditional knowledge has

424

425

426

427

428

429

430 been shown to be effective in certain locations in Hawai' $i$, as well as other locations in the

Pacific (Poepoe, Bartram \& Friedlander, 2005; Friedlander, Shackeroff \& Kittinger, 2013;

Severance et al., 2013; Levine \& Richmond, 2014; Birkeland, 2017). A diverse range of

management options needs to be developed through a collaborative approach. There is a strong

movement in Hawai'i toward decentralized fisheries management, with a revitalization of

community-based fishery management based on customary practices and knowledge

(Friedlander, Shackeroff \& Kittinger, 2013; Vaughan \& Vitousek, 2013), including a recent legal 
431 mandate for collaborative management between the state and local communities to establish

432 Community-Based Subsistence Fishing Areas (Kittinger et al., 2012; Ayers \& Kittinger, 2014).

433 There are over 20 community initiatives currently active in Hawai'i (Ayers \& Kittinger, 2014),

434 which is among the most promising developments in nearshore fishery management. In Hawai ${ }^{\circ} \mathrm{i}$,

435 the cultural diversity and isolation of the islands lead to many expressions of self-determination;

436 one of those expressions is the desire for "local production for local consumption, under local

437 control" (Loke \& Leung, 2013). At all sites where fish flow surveys were conducted, the

438 majority of fish caught was either kept or given away for local consumption, demonstrating the

439 high food security and cultural value of these non-commercial subsistence/recreational fisheries

440 for the people of Hawai' $i$, particularly in rural areas.

441 Direct translation of traditional practices into a modern management context is often not

442 possible for political and historical reasons. Current management strategies are often an

443 adaptation and melding of traditional with the contemporary (Cinner \& Aswani, 2007;

444 Shackeroff \& Campbell, 2007; Jokiel et al., 2011; Ayers \& Kittinger, 2014). Movement towards

445 the establishment of more co-management arrangements is also driven by recent findings that

446 locations under community-based management have similar amounts or greater fish biomass

447 compared to no-take protected areas (Friedlander, Shackeroff \& Kittinger, 2013). Both of these

448 management regimes harbor higher biomass than partially protected or completely open-access

449 areas, clearly indicating that community-managed areas can be effective in providing positive

450 ecological outcomes by sustaining both ecosystems and ecosystem benefits (Friedlander,

451 Shackeroff \& Kittinger, 2013). 

negative fishing impacts in coral reefs and other marine environments (Sumaila, Alder \& Keith, 2006), with a lack of awareness on local regulations, as well as weak law enforcement, acting as

456 key contributing factors for lack of compliance (Bergseth, Russ \& Cinner, 2015). In Hawai'i, 457 survey results show that fishers identify weak enforcement of fisheries laws as a top threat to 458 fishery resources (OmniTrak, 2011), and lack of compliance and weak enforcement is one of the 459 priority threats to Hawaiian coral reefs and a key capacity gap. violations at some locations. Violations at sites ranged from harvested undersized fish, take of prohibited species, use of illegal gears, and fishing in off-limit areas. Instances of illegal fishing and the spatial and temporal patterns of fishing catch and effort have important management implications, and such trends help guide strategies to optimally monitor fisheries given logistical limitations (e.g., limited time, equipment, and personnel to monitor vast amount of area). For this reason, managers and scientists cannot monitor the entire geographic areas of most coral reef fisheries as intensely as needed. In these situations, local monitoring efforts are critical to inform place-based management (McClanahan \& Mangi, 2004; McClanahan et al., 2006). However, these local monitoring efforts also need to be aggregated into broader analyses of temporal and spatial scales for managers to gain insights about fishery trends and appropriate management 472 approaches.

474 activities (e.g., Kahekili [Friedlander et al., 2012]), but also potentially reduce them (Kīholo 475 [Kittinger et al., 2015]). More enforcement capacity will be required in order to better support 
476 existing input and output regulations as well as new rules being advanced through community-

477 led initiatives and state-wide initiatives (such as scoping the feasibility of a licensing system).

478 Creel surveys could be better integrated with these educational and enforcement programs to

479 inform these efforts.

480 To best monitor legal and IUU fishing, we need to determine the most effective survey

481 approach for a given set of personnel, geographies, and available resources. For example, many

482 coastal areas in Hawai'i are expansive and relatively undeveloped. Access points to these areas

483 are generally indistinct and parking haphazardly on the side of a road is common. Local fishers

484 often prefer to utilize these areas where resources are generally not as depleted. In addition to

485 many line fishers, spear and net fishers tend to favor remote areas where capture success is likely

486 greater due to higher resource availability. Based upon the general characteristics of the coastal

487 areas and the diversity of shore-based fisheries in Hawai' ${ }^{\prime} i$, the roving survey is often considered

488 the more suitable survey method to collect shoreline fishing information. Also, given that fishing

489 effort is generally higher on weekends and holidays during non-winter months, optimally

490 allocating limited effort for monitoring to those times and locations with higher fishing pressure,

491 could possibly lead to better coverage of fishing activities as well as better enforcement of

492 current regulations. Community monitoring can detect illegal activities, but also potentially

493 reduce them (Kittinger et al., 2015). Also, more enforcement capacity will be required to better

494 support existing input and output regulations. Some promising initiatives include the Community

495 Fisheries Enforcement Unit, Makai Watch, and other existing initiatives in Hawai'i. Creel

496 surveys could be better integrated with these educational and enforcement programs. 

fisheries monitoring (Pauly \& Zeller, 2014), thus making fishing effort and total annual catch

500 poorly understood and difficult to quantify (Zeller et al., 2006; McCoy, 2015; Gillett, 2016).

501 These realities behoove us to identify cost-effective and accurate monitoring tools and survey 502 instruments to appropriately track ecological and social aspects of small-scale tropical fisheries, 503 the results of which can successfully inform adaptive state and community-level fisheries 504 management. To address this, Hawai' $\mathrm{i}$ is currently exploring a range of options, including 505 requiring recreational fishing licenses and/or reporting of recreational/non-commercial fisheries, 506 which would provide critical information on non-commercial catch and effort (Noncommercial 507 fisheries licensing steering committee, 2016).

In many of the locations, fishing effort was typically higher on the weekends and

509 holidays than on weekdays (Hayes et al., 1982; Friedlander \& Parrish, 1997; Koike et al., 2015).

510 Along north facing shores, fishing effort was constrained in winter due to large surf (Everson \&

511 Friedlander, 2004; Koike, Carpio \& Friedlander, 2014). Many locations in Hawai'i, particularly

512 sandy shores and embayments, experience higher fishing effort during summer (June-August)

513 when juvenile goatfishes aggregate in mass very close to shore (Kamikawa, 2016). Summer

514 months also experienced higher fishing pressure because school is not in session and weather

515 conditions are typically more favorable, allowing more people to spend more time fishing with

516 their families.

517 We recommend that creel surveys be conducted in a more standardized fashion, more 518 regularly, and at additional sites, to provide more standardized data that has better spatial and 519 temporal coverage, which will allow for more robust analyses. This is critical to address a variety 520 of management issues. First, fishing effort and catch can change, not only across space, but also 
521 over time. For example, estimates were quite different at Puakō between surveys of the area in

522 1980-1981 and 2008-2009. Yet the exact location and size of the study site varied between

523 surveys, which makes comparison more challenging. Nevertheless, current estimates of catch

524 and effort could also be quite different for Hanalei Bay and Kāne'ohe Bay, which were surveyed

525 in 1992-1993 and 1991-1992, respectively. Therefore, repeat sampling of the same areas through

526 time is needed. The surveys of 18 sites were conducted over decades, which does not allow for

527 spatial and temporal aspects to be disentangled, which would have great importance for

528 conservation and management actions. Furthermore, the information reported from these surveys

529 hampered full analysis of the data. For example, some creel surveys only reported some of the

530 species and/or family-level catch data. Another example is that some studies reported effort in

531 semi-quantitative measures (e.g., frequency of occurrence) or number of fishers rather than the

532 more preferred form of gear-hours, which better allows for estimates of effort and comparison

533 among sites. These issues of standardization hindered the ability to conduct some analyses and

534 forced us to look at coarse measures such as overall catch and effort. The execution of future

535 creel surveys in a more standardized fashion will be of greater benefit to research and

536 management. We recommend that when these data are available, analyses are conducted to the

537 species-level, comparisons of catch and effort on a finer scale (e.g., within a survey area, better

538 differentiation of gear types [e.g., cast net, laynet, surround nets]). Additionally, we recommend

539 examining how fishing effort and catch vary across space and time, which was not possible in

540 our study due to limited and non-standardized reporting of the creel surveys that were previously

541 conducted.

542

543 Conclusion: 
545 threatened by a range of factors including overfishing, pollution, invasive species, climate

546 change, and other threats. Our research reveals regional patterns in harvesting in these complex

547 fisheries, which can be used to inform a range of regulatory approaches to rebuild these fisheries.

548 Together with reductions in land-based pollution, invasive species control, and other measures,

549 managing these local drivers can help reefs be more resilient to climate change, a global threat

550 that is undermining reef ecosystems across the planet (Hughes et al., 2017). Site-based survey

551 methods that are led by community groups can also provide benefits in co-learning, reduction of

552 illegal and harmful activities, and building community capacity, which are necessary for

553 effective stewardship (Kittinger, 2013). In an era where the threats to reefs and their associated

554 fisheries are escalating due to overfishing, pollution, and climate change (Bell, Johnson \&

555 Hobday, 2011), local efforts must be embedded into broader regional management efforts if reefs

556 and the benefits they provide to people are to survive.

557

558 Acknowledgments:

We would like to thank all the communities, organizations, funders, and individuals that were involved with any stage of the surveys, the editor, and two anonymous reviewers. We thank and we thank Joey Lecky and Hla Htun for GIS data that we built upon. 
565 Albert S., Aswani S., Fisher PL., Albert J. 2015a. Keeping food on the table: human responses

566 and changing coastal fisheries in Solomon Islands. PLOS One 10:e130800.

567 Albert JA., Olds AD., Albert S., Cruz-Trinidad A., Schwarz A-M. 2015b. Reaping the reef:

568 Provisioning services from coral reefs in Solomon Islands. Marine Policy 62:244-251.

569 DOI: 10.1016/j.marpol.2015.09.023.

570 Anderson SC., Cooper AB., Jensen OP., Minto C., Thorson JT., Walsh JC., Afflerbach J.,

571 Dickey-Collas M., Kleisner KM., Longo C., Osio GC., Ovando D., Mosqueira I.,

572 Rosenberg AA., Selig ER. 2017. Improving estimates of population status and trend with

$573 \quad$ superensemble models. Fish and Fisheries.

574 Ayers AL., Kittinger JN. 2014. Emergence of co-management governance for Hawai'i coral reef

575 fisheries. Global Environmental Change 28:251-262.

576 Battista T., Costa B., Anderson SM. 2007. Shallow-Water Benthic Habitats of the Main Eight

577 Hawaiian Islands. NOAA Technical Memorandum NOS NCCOS 61.

578 Bell JD., Johnson JE., Hobday AJ. 2011. Vulnerability of tropical Pacific fisheries and 579 aquaculture to climate change. SPC FAME Digital Library.

580 Bell JD., Kronen M., Vunisea A., Nash WJ., Keeble G., Demmke A., Pontifex S., Andréfouët S. 581 2009. Planning the use of fish for food security in the Pacific. Marine Policy 1:64-76.

582 DOI: 10.1016/j.marpol.2008.04.002.

583 Bergseth BJ., Russ GR., Cinner JE. 2015. Measuring and monitoring compliance in no-take 584 marine reserves. Fish and Fisheries 16:240-258.

585 Birkeland C. 2017. Working with, not against, coral-reef fisheries. Coral Reefs 36. DOI:

586 10.1007/s00338-016-1535-8. 
587 Blaber SJ., Cyrus D., Albaret J-J., Ching CV., Day J., Elliott M., Fonseca M., Hoss D., Orensanz 588 J., Potter I., others 2000. Effects of fishing on the structure and functioning of estuarine 589 and nearshore ecosystems. ICES Journal of Marine Science 57:590-602.

590 Cesar HS., Van Beukering P. 2004. Economic valuation of the coral reefs of Hawai'i. Pacific $591 \quad$ Science 58:231-242.

592 Cinner JE., Aswani S. 2007. Integrating customary management into marine conservation. 593 Biological Conservation 140:201-216.

594 Cinner JE., McClanahan TR., Daw TM., Graham NA., Maina J., Wilson SK., Hughes TP. 2009 a. 595 Linking social and ecological systems to sustain coral reef fisheries. Current Biology 596 $19: 206-212$.

597 598

600

601

602

603

604

605

606

607

608

Cinner JE., McClanahan TR., Graham NAJ., Pratchett MS., Wilson SK., Raina J-B. 2009b. Gear-based fisheries management as a potential adaptive response to climate change and coral mortality. Journal of Applied Ecology 46:724-732.

Cinner JE., McClanahan TR., MacNeil MA., Graham NA., Daw TM., Mukminin A., Feary DA., Rabearisoa AL., Wamukota A., Jiddawi N., Campbell SJ., Baird AH., JanuchowskiHartley FA., Hamed S., Lahari R., Morove T., Kuange J. 2012. Comanagement of coral reef social-ecological systems. Proceedings of the National Academy of Sciences 109:5219-5222.

Costello MJ., Wilson S., Houlding B. 2012. Predicting total global species richness using rates of species description and estimates of taxonomic effort. Systematic Biology 61:871-883.

Dalzell P. 1996. Catch rates, selectivity and yields of reef fishing. In: Reef fisheries. Springer, $161-192$. 
609 Division of Aquatic Resources. 2017. Regulations. Available at:

610 http://dlnr.hawaii.gov/dar/fishing/fishing-regulations/. Accessed 15 March 2017.

611 Dollar S. 1982. Wave stress and coral community structure in Hawai'i. Coral Reefs 1:71-81.

612 Donovan MK., Friedlander AM., Usseglio P., Goodell W., Iglesias I., Schemmel EM., Stamoulis

613

614

615

616

617

618

619

620

621

622

623

624

625

626

627

628

629

630

KA., Filous A., Giddens J., Kamikawa K., Koike H., McCoy K., Wall CB. 2016. Effects of Gear Restriction on the Abundance of Juvenile Fishes along Sandy Beaches in Hawai'‘. PLOS One 11:e0155221.

ESRI. 2011. ArcGIS Desktop: Release 10. Environmental Systems Research Institute. Redlands, CA. Available at: http://www. esri.com/. Accessed 8 June 2016.

Everson A., Friedlander AM. 2004. Catch, effort, and yields for coral reef fisheries in Kāne'ohe Bay, O`ahu and Hanalei Bay, Kaua'i: Comparisons between a large urban and a small rural embayment. Status of Hawaii's Coastal Fisheries in the New Millennium:110-131.

Fenner D. 2012. Challenges for managing fisheries on diverse coral reefs. Diversity 4:105-160.

Friedlander AM. 2015. A perspective on the management of coral reef fisheries. Ecology of Fishes on Coral Reefs:208-214.

Friedlander A., Aeby G., Brainard R., Brown E., Chaston K., Clark A., McGowan P., Montgomery T., Walsh W., Williams I., Witse W. 2008. The state of coral reef ecosystems of the main Hawaiian Islands. The state of coral reef ecosystems of the United States and Pacific freely associated states:222-269.

Friedlander A., Brown E., Jokiel P., Smith W., Rodgers K. 2003. Effects of habitat, wave exposure, and marine protected area status on coral reef fish assemblages in the Hawaiian archipelago. Coral Reefs 22:291-305. 
631 Friedlander AM., Brown EK., Monaco ME. 2007. Coupling ecology and GIS to evaluate 632 efficacy of marine protected areas in Hawai'i. Ecological Applications 17:715-730.

633 Friedlander A., Curry P., Filous A., Giddens J., Gooddell W., Kamikawa K., Koike H., Schemme 634 E., Stamoulis K., Usseglio P. 2014a. Assessing lay-gillnet regulations in protected and 635 unprotected areas on windward O'ahu Final Report. Final Report to the Castle

636 Foundation.

637 Friedlander AM., DeMartini EE. 2002. Contrasts in density, size, and biomass of reef fishes 638 between the northwestern and the main Hawaiian islands: the effects of fishing down 639 apex predators. Marine Ecology Progress Series 230:253-264.

640

641

642

643

644

645

646

647

648

649

650

651

652 653

Friedlander A., Donovan M., Stamoulis K., Williams I., Brown E., Conklin E., DeMartini E., Rodgers K., Sparks R., Walsh W. 2017. Human-induced gradients of reef fish declines in the Hawaiian Archipelago viewed through the lens of traditional management. Aquatic Conservation: Marine and Freshwater Ecosystems. Available at: http://onlinelibrary.wiley.com/doi/10.1002/aqc.2832/full. Accessed 10 September 2017.

Friedlander AM., Koike H., Kekoa L., Sparks R. 2012. Design, development, and implementation of a survey of the fisheries of Kahekili Herbivore Fisheries Management Area. Final Report submitted to State of Hawai'i, Department of Land and Natural Resources, Division of Aquatic Resources.

Friedlander AM., Nowlis J., Koike H. 2014. Improving Fisheries Assessments Using Historical Data. Marine Historical Ecology in Conservation: Applying the Past to Manage for the Future:91.

Friedlander AM., Parrish JD. 1997. Fisheries harvest and standing stock in a Hawaiian Bay. Fisheries Research 32:33-50. 
654 Friedlander AM., Shackeroff JM., Kittinger JN. 2013. Customary marine resource knowledge 655 and use in contemporary Hawai'i. Pacific Science 67:441-460.

656 Friedlander AM., Stamoulis KA., Kittinger JN., Drazen J., Tissot BN. 2014b. Understanding the 657 scale of marine protection in Hawai' $\mathrm{i}$ : from community-based management to the remote 658

659 northwestern Hawaiian Islands Marine National Monument. Advances in Marine Biology

660

661

662

663

664

665

666

667

668

669

670

671

672

673

674

675

676 69:153-203.

Gaines SD., White C., Carr MH., Palumbi SR. 2010. Designing marine reserve networks for both conservation and fisheries management. Proceedings of the National Academy of Sciences 107:18286-18293.

Giddens J. 2010. Assessment of Near-Shore Fishing in Puakō, West Hawai 'i from December 2008-2009. Report For The Nature Conservancy Hawai‘i Marine Program.

Gillett R. 2016. Fisheries in the Economies of Pacific Island Countries and Territories. Secretariat of the Pacific Community.

Gillett R., Moy W. 2006. Spearfishing in the Pacific Islands: current status and management issues.

Glazier E., Kittinger J. 2012. Fishing, seafood, and community research in the main Hawaiian Islands: a case study of Hanalei Bay, Kaua 'i. Honolulu: Impact Assessment, Inc. (IAI). Final Report Prepared for State of Hawai‘i, Department of Land and Natural Resources, Division of Aquatic Resources.

Gove JM., Williams GJ., McManus MA., Heron SF., Sandin SA., Vetter OJ., Foley DG. 2013. Quantifying climatological ranges and anomalies for Pacific coral reef ecosystems. PloS one 8:e61974.

Hardt MJ. 2011. The Flow of Fish. A Report for The Kohala Center, prepared by OceanInk. 
677 Hayes T., Hourigan T., Jazwinski S., Johnson S., Parrish J., Walsh D. 1982. The coastal

678

679

680

681

682

683

684

685

686

687

688

689

690

691

692

693

694

695

696

697

698

resources, fisheries and fishery ecology of Puakō, West Hawai'i. Hawai ‘i Cooperative Fishery Research Unit Technical Report 82:153-156.

Hilborn R., Ovando D. 2014. Reflections on the success of traditional fisheries management. ICES Journal of Marine Science 71:1040-1046.

Houk P., Rhodes K., Cuetos-Bueno J., Lindfield S., Fread V., McIlwain J. 2012. Commercial coral-reef fisheries across Micronesia: a need for improving management. Coral Reefs $31: 13-26$.

Hughes TP., Barnes ML., Bellwood DR., Cinner JE., Cumming GS., Jackson JB., Kleypas J., van de Leemput IA., Lough JM., Morrison TH., Palumbi SR., van Nes EH., Scheffer M. 2017. Coral reefs in the Anthropocene. Nature 546:82-90.

Johannes RE. 1978. Traditional marine conservation methods in Oceania and their demise. Annual Review of Ecology and Systematics 9:349-364.

Jokiel P., Rodgers K., Walsh W., Polhemus D., Wilhelm T. 2011. Marine resource management in the Hawaiian Archipelago: the traditional Hawaiian system in relation to the Western approach. Journal of Marine Biology 2011.

Kamikawa KT. 2016. Insight into seasonal recruitment dynamics of juvenile Mulloidichthys vanicolensis and M. flavolineatus. M.Sc. Thesis. The University of Hawai'‘i.

Kittinger JN. 2013. Participatory Fishing Community Assessments to Support Coral Reef Fisheries Comanagement. Pacific Science 67:361-381.

Kittinger J., Finkbeiner E., Glazier E., Crowder L. 2012. Human dimensions of coral reef socialecological systems. Ecology and Society 17:17. 
699 Kittinger JN., Teneva LT., Koike H., Stamoulis KA., Kittinger DS., Oleson KL., Conklin E., 700 Gomes M., Wilcox B., Friedlander AM. 2015. From reef to table: social and ecological

701

702

703

704

705

706

707

708

709

710

711

712

713

714

715

716

717

718

719

720

721 factors affecting coral reef fisheries, artisanal seafood supply chains, and seafood security. PLOS One 10:e0123856.

Koike H., Carpio J., Friedlander AM. 2014. Final Creel Survey Report for Wailuku Community Management Area, Maui County, Hawai ‘i. Final Report Submitted to Conservation International Hawai'i.

Koike H., Wiggins C., Most R., Conklin E., Minton D., Friedlander AM. 2015. Final Creel Survey Report for Ka 'üpūlehu Creel Survey Project, North Kona, Hawai'i Island. Final Report Submitted to The Nature Conservancy.

Kronen M., Magron F., McArdle B., Vunisea A. 2010a. Reef finfishing pressure risk model for Pacific Island countries and territories. Fisheries Research 101:1-10.

Kronen M., Vunisea A., Magron F., McArdle B. 2010b. Socio-economic drivers and indicators for artisanal coastal fisheries in Pacific island countries and territories and their use for fisheries management strategies. Marine Policy 34:1135-1143.

Lester SE., Halpern BS., Grorud-Colvert K., Lubchenco J., Ruttenberg BI., Gaines SD., Airamé S., Warner RR. 2009. Biological effects within no-take marine reserves: a global synthesis. Marine Ecology Progress Series 384:33-46.

Levine AS., Richmond LS. 2014. Examining enabling conditions for community-based fisheries comanagement: comparing efforts in Hawai'i and American Samoa. Ecology and Society 19:24.

Lindfield SJ., McIlwain JL., Harvey ES. 2014. Depth refuge and the impacts of SCUBA spearfishing on coral reef fishes. PLOS One 9:e92628. 
722 Loke MK., Leung P. 2013. Hawaii’s food consumption and supply sources: benchmark estimates and measurement issues. Agricultural and Food Economics 1:10.

724

725

726

727

728

729

730

731

732

733

734

735

736

737

738

739

740

741

742

743

744

Lubchenco J., Palumbi SR., Gaines SD., Andelman S. 2003. Plugging a hole in the ocean: the emerging science of marine reserves. Ecological applications 13:S3-S7.

Malvestuto S. 1983. Sampling the recreational fishery. In: In "Fisheries Techniques" (Nielsen, LA and DL Johnson, Eds.), pp. 397-419. American Fisheries Society, Bethesda, MD.

Malvestuto SP. 1996. Sampling the recreational creel. Fisheries techniques, 2nd edition. American Fisheries Society, Bethesda, Maryland:591-623.

Malvestuto SP., Davies WD., Shelton WL. 1978. An evaluation of the roving creel survey with nonuniform probability sampling. Transactions of the American Fisheries Society 107:255-262.

McClanahan T., Cinner J. 2008. A framework for adaptive gear and ecosystem-based management in the artisanal coral reef fishery of Papua New Guinea. Aquatic Conservation: Marine and Freshwater Ecosystems 18:493-507.

McClanahan TR., Graham NA., MacNeil MA., Muthiga NA., Cinner JE., Bruggemann JH., Wilson SK. 2011. Critical thresholds and tangible targets for ecosystem-based management of coral reef fisheries. Proceedings of the National Academy of Sciences 108:17230-17233.

McClanahan T., Maina J., Davies J. 2005. Perceptions of resource users and managers towards fisheries management options in Kenyan coral reefs. Fisheries Management and Ecology 12:105-112.

McClanahan TR., Mangi S. 2000. Spillover of exploitable fishes from a marine park and its effect on the adjacent fishery. Ecological Applications 10:1792-1805. 
745 McClanahan T., Mangi S. 2004. Gear-based management of a tropical artisanal fishery based on species selectivity and capture size. Fisheries Management and Ecology 11:51-60.

747

748

749

750

751

752

753

754

755

756

757

758

759

760

761

762

763

764

765

766

767

McClanahan TR., Marnane MJ., Cinner JE., Kiene WE. 2006. A comparison of marine protected areas and alternative approaches to coral-reef management. Current Biology 16:14081413.

McCoy K. 2015. Estimating nearshore fisheries catch for the main Hawaiian Islands. M.Sc. Thesis. The University of Hawai' $i$.

Meyer CG. 2003. An empirical evaluation of the design and function of a small marine reserve (Waikīkī Marine Life Conservation District). Ph.D. Thesis. The University of Hawai'i. Nadon MO. 2017. Stock assessment of the coral reeffishes of Hawaii, 2016. U.S. Dep. Commer., NOAA Tech. Memo., NOAA-TM-NMFS-PIFSC-60, 212 p. doi:10.7289/V5/TM-PIFSC60.

Nadon MO., Ault JS., Williams ID., Smith SG., DiNardo GT. 2015. Length-based assessment of coral reef fish populations in the Main and Northwestern Hawaiian Islands. PLOS One 10:e0133960.

Newton K., Cote IM., Pilling GM., Jennings S., Dulvy NK. 2007. Current and future sustainability of island coral reef fisheries. Current Biology 17:655-658.

Noncommercial fisheries licensing steering committee. 2016. Feasibility of a non-commercial marine fishing registry, permit, or license system in Hawai 'i. State of Hawai' $i$ Department of Land and Natural Resources. Available at: http://dlnr.hawaii.gov/dar/announcements/feasibility-of-a-non-commercial-marinefishing-registry-permit-or-license-system-in-hawaii/. Accessed 7 September 2017. OmniTrak. 2011. Hawai 'i Fish Trust 2011 Seafood Security Study. A report on project \#5042. 
768 Pauly D. 2006. Major trends in small-scale fisheries, with emphasis on developing countries, and 769 some implications for the social sciences. Maritime Studies 4:7-22.

770 Pauly D., Zeller D. 2014. Accurate catches and the sustainability of coral reef fisheries. Current $771 \quad$ Opinion in Environmental Sustainability 7:44-51.

772 Poepoe KK., Bartram PK., Friedlander AM. 2005. The use of traditional knowledge in the

773

774

775

776

777

778

779

780

781

782

783

784

785

786

787

788

789

790 contemporary management of a Hawaiian community's marine resources. In: Haggan N, Neis B, Baird IG eds. Fishers’ knowledge in fisheries science and management. Chapter 6. UNESCO-LINKS, 437.

Pollock KH., Hoenig JM., Jones CM., Robson DS., Greene CJ. 1997. Catch rate estimation for roving and access point surveys. North American Journal of Fisheries Management $17: 11-19$.

Prince J., Victor S., Kloulchad V., Hordyk A. 2015. Length based SPR assessment of eleven Indo-Pacific coral reef fish populations in Palau. Fisheries Research 171:42-58.

Ricard D., Minto C., Jensen OP., Baum JK. 2012. Examining the knowledge base and status of commercially exploited marine species with the RAM Legacy Stock Assessment Database. Fish and Fisheries 13:380-398.

Richmond R., Kelty R., Craig P., Emaurois C., Green A., Birkeland C., Davis G., Edward A., Golbuu Y., Gutierrez J., Houk P., Idechong N., Maragos J., Paulay G., Starmer J., Tafileichig A., Trianni M., Velde NV. 2002. Status of the coral reefs in Micronesia and American Samoa: US affiliated and freely associated islands in the Pacific. Status of Coral Reefs of the World: 2002:217-236.

Robson D., Jones CM. 1989. The theoretical basis of an access site angler survey design. Biometrics 45:83-98. 
791 Rosenberg AA., Kleisner KM., Afflerbach J., Anderson SC., Dickey-Collas M., Cooper AB., 792 Fogarty MJ., Fulton EA., Gutiérrez NL., Hyde KJW., Jardim E., Jensen OP., Kristiansen

793

794

795

796

797

798

799

800

801

802

803

804

805

806

807

808

809

810

811

812
T., Longo C., Minte-Vera CV., Minto C., Mosqueira I., Osio GC., Ovando D., Selig ER., Thorson JT., Walsh JC., Ye Y. 2017. Applying a new ensemble approach to estimating stock status of marine fisheries around the world. Conservation Letters.

Sabetian A., Foale S. 2006. Evolution of the artisanal fisher: Case studies from Solomon Islands and Papua New Guinea. Traditional Marine Resource Management and Knowledge Information Bulletin 20:3-10.

Sale PF. 2008. Management of coral reefs: where we have gone wrong and what we can do about it. Marine Pollution Bulletin 56:805-809.

Schemmel E., Friedlander A. 2017. Participatory fishery monitoring is successful for understanding the reproductive biology needed for local fisheries management. Environmental Biology of Fishes 100:171-185.

Scholz A., Bonzon K., Fujita R., Benjamin N., Woodling N., Black P., Steinback C. 2004. Participatory socioeconomic analysis: drawing on fishermen's knowledge for marine protected area planning in California. Marine Policy 28:335-349.

Severance C., Franco R., Hamnett M., Anderson C., Aitaoto F. 2013. Effort Triggers, Fish Flow, and Customary Exchange in American Samoa and the Northern Marianas: Critical Human Dimensions of Western Pacific Fisheries. Pacific Science 67:383-393.

Shackeroff JM., Campbell LM. 2007. Traditional ecological knowledge in conservation research: problems and prospects for their constructive engagement. Conservation and Society $5: 343$. 
813 Smith MK. 1993. An ecological perspective on inshore fisheries in the main Hawaiian Islands. $814 \quad$ Marine Fisheries Review 55:34-49.

815 Smith MK. 1993. An ecological perspective on inshore fisheries in the main Hawaiian Islands. $816 \quad$ Marine Fisheries Review 55:34-49.

817 Stamoulis KA., Friedlander AM. 2013. A seascape approach to investigating fish spillover across 818 a marine protected area boundary in Hawai'i. Fisheries Research 144:2-14.

819 State of Hawai'i. 2010. 2010 Census Data, Census Blocks - 2010, Cultural and Demographic, GIS Data. Data from U.S. Census Bureau. State of Hawai‘i, Office of Planning, Hawai‘i Statewide GIS Program. Data Downloaded September 2015. Available at: http://planning.hawaii.gov/gis/download-gis-data-expanded/. Accessed 30 September 2015.

Stevenson DK., Marshall N. 1974. Generalisations on the fisheries potential of coral reefs and adjacent shallow-water environments. In: Proc. 2nd Int. Coral Reef Symp. 147-156.

Sumaila UR., Alder J., Keith H. 2006. Global scope and economics of illegal fishing. Marine Policy 30:696-703. PLOS One 8:e65397.

Tom SK. 2011. An investigation of the cultural use and population characteristics of opihi (Mollusca: Cellana spp.) at Kalaupapa National Historical Park. M.Sc. Thesis. The University of Hawai'i.

UN FAO. 2016. The State of World Fisheries and Aquaculture 2016 (SOFIA): Contributing to 834 food security and nutrition for all. 
835 Vaughan MB., Vitousek PM. 2013. Mahele: Sustaining Communities through Small-Scale 836 Inshore Fishery Catch and Sharing Networks. Pacific Science 67:329-344.

837 Walters CJ., Martell SJ. 2004. Fisheries ecology and management. Princeton University Press.

838 Weijerman M., Williams I., Gutierrez J., Grafeld S., Tibbatts B., Davis G. 2016. Trends in 839 biomass of coral reef fishes, derived from shore-based creel surveys in Guam. Fishery Bulletin 114:237-257.

Western Pacific Regional Fisheries Management Council (WPRFMC). 2009. Fishery Ecosystem Plan for the Hawai 'i Archipelago. Honolulu, Hawai'i.

843

844

Whyte WF., Greenwood DJ., Lazes P. 1989. Participatory action research: Through practice to science in social research. American Behavioral Scientist 32:513-551.

Williams I., Walsh W., Miyasaka A., Friedlander A. 2006. Effects of rotational closure on coral reef fishes in Waikīkī-Diamond head fishery management area, $\mathrm{O}$ ‘ahu, Hawai‘i. Marine Ecology Progress Series 310:139-149.

Williams I., Walsh W., Schroeder R., Friedlander A., Richards B., Stamoulis K. 2008. Assessing the importance of fishing impacts on Hawaiian coral reef fish assemblages along regional-scale human population gradients. Environmental Conservation 35:261-272.

Williams ID., White DJ., Sparks RT., Lino KC., Zamzow JP., Kelly EL., Ramey HL. 2016. Responses of herbivorous fishes and benthos to 6 years of protection at the Kahekili Herbivore Fisheries Management Area, Maui. PLoS one 11:e0159100.

Wolfe B., Goodell W., Stender Y., Friedlander AM. 2017. Creel Survey Joint Base Pearl Harbor-Hickam Joint Base Pearl Harbor-Hickam, Navy Region Hawai ‘i.

Worm B., Hilborn R., Baum JK., Branch TA., Collie JS., Costello C., Fogarty MJ., Fulton EA., Hutchings JA., Jennings S., Jensen OP, Lotze HK., Mace PM., McClanahan TR., Minto 
858 C., Palumbi SR., Parma AM., Ricard D., Rosenberg AA., Watson R., Zeller D. 2009.

$859 \quad$ Rebuilding global fisheries. Science 325:578-585.

860 Zeller D., Booth S., Craig P., Pauly D. 2006. Reconstruction of coral reef fisheries catches in

$861 \quad$ American Samoa, 1950-2002. Coral Reefs 25:144-152.

862 